\title{
Economic and Social Impacts of Public Schools Management on the City of New Orleans and the State of Louisiana
}

Matthew Uwakonye

Grambling State University

Gbolahan S. Osho

Prairie View A\&M University

Onochie Jude Dieli

Prairie View A\&M University

Michael Adams

Texas Southern University

Received: July 16, 2020 Accepted: August 27, $2020 \quad$ Published: September 28, 2020

doi:10.5296/jpmr.v6i2.17359 URL: https://doi.org/10.5296/jpmr.v6i2.17359

\begin{abstract}
Poverty, illiteracy, and crimes are key factors that commonly lead to poor performance in public schools in many inner cities. Without an adequate solution to eradicate these issues, a city could propel towards a path to destruction. Over the past decade, the city of New Orleans, which is known for its exotic party atmosphere, has been crippled by its failing school system, as well as increasing crime and poverty rates. New Orleans has eagerly strived to improve its social stature, but there are several issues that affect the performance of the public school system. Several research studies have shown that strong education is the key to both economic growth and crime rate reduction. Within the city of New Orleans, it is often realized that the management of the public school system has a major impact on the student's success rate. Statistics shown that within the recent years, tests scores have been continuously lower, crime has been higher than expected, and the teacher's salary has been unsatisfactory.
\end{abstract}


This prompts the question of whether there are significant associations between social economic factors and public school performance in inner city such as New Orleans. Hence, this current research will attempt to examine factors contributing to public school performance in New Orleans.

Keywords: New Orleans, public school performance, and social economic factors

\section{Introduction}

Over the past few years, the crime and poverty levels of New Orleans have fluctuated immensely. Many local officials, activists, socialists, psychologists, and parents have debated over education and its role regarding the city's shifting poverty and crime rate. Through the years, New Orleans has ranked in the bottom of each national list in poverty, education, and crime. Each issue has been an enormous factor that has adversely affected the perceptions of the city. While there have students that have successfully advanced within the New Orleans public school system, however many have been left behind. This is usually due to insufficient funds, ignorance of academics, and a negative outlook on life.

In the city of New Orleans, the superintendent is the executive officer of the school board, where their decisions a major factor on students and teachers' productivity. In addition, several students are often fall short of yearly advancement tests and standardized tests such as the ACT and SAT. The superintendent is to ensure that teachers are certified, as well as receiving adequate amount of funds for their services. In addition to a teacher's certification, the superintendent must also ensure that there are updated books and programs within schools. The superintendents as administrators have to ensure that each school is safe and has a nurturing environment. If not corrected, these are all issues that often affect a productive school system as well as its expected outcome for its students. Hence, this prompts the question of whether there are significant associations between social economic factors and public school performance in inner city such as New Orleans. Hence, this current research will seek to examine and evaluate several factors contributing to public school performance in New Orleans.

\section{Literature Review}

Unique and diverse in culture, New Orleans has consistently entertained many people around the world through events such as Mardi Gras, Jazz Fest, and even the Super Bowl. It is one of the cities known to promote carefree relaxation as well as an ultimate party. When all the parties are over, the city of New Orleans lives up to its name. While tourism and nation-wide events are heavily promoted, poverty, crime and education are placed on the back burner. Through the years, this influential city has struggled to improve its crime rate, high poverty, and unorganized educational system. In 2004, a staff member from the City Business and a local newspaper wrote an article discussing New Orleans's ranking as the third most stressful city in the United States. The rank reflected the high rates of poverty, violent crime, and unemployment that prevailed within the city. This ranking was out of three-hundred and thirty-three metropolitan cities. Tacoma, Washington and Miami, Florida were first and second on the list as most stressful cities. The factors determined in this ranking included those such as crime, poverty, suicide, divorce rates and alcohol 
consumption.

In 2006, Lynne Jensen, a staff writer for the Times-Picayune, wrote an article about the state of Louisiana ranking $49^{\text {th }}$ in nurturing children. In this article, Jensen discussed the decrease birth rate of infants in Louisiana, along with the decline of students in school and working for the state, propelling their rank to the bottom of the list. In the last few years, Louisiana has ranked in the bottom of the United States Census Bureau regarding poverty and crime. In 2003, Louisiana ranked \#1 with 20.3 percent people living below the poverty level, while in 2004 Louisiana ranked \#6 of states with violent crime. This is a statewide issue, even though New Orleans and Baton Rouge, the state capital, are the highest contributors in the statistical outcome.

With issues such as crime and poverty in the air, the issue of productive and sufficient education is often overshadowed. Education is the key factor in influencing success as it gives people a chance to believe in change and success in the future. Without education, many children are steered down a dangerous road, which leads to crime, poverty, and even death.

The public schools in New Orleans do not meet the expectations of many parents or students. Parents send their children to school to learn, but are distracted by fights and inadequate academic equipment, which renders them unable to learn. Do these issues exist in private schools or other parts of the United States? Instead of education filtering through children's brains at the local high schools, students struggle to focus on their academics in the midst of dangerous situations.

Brett Martel (2000) wrote an article depicting the shootings in the New Orleans area, most of which involved students who should have been in school. One incident involved a thirteen-year old boy who brought a gun to school because of a conflict with another young man within a rival neighborhood. The school that he attended looked exactly like its surrounding neighborhood - dark with barbed wired. It was located by housing projects, neglected houses, and broken glass. Where is the management? How can a child be expected to learn and not fight in an environment like this? How was he able to bring a gun to school? How can any child reach any level of achievement?

Hallinam (1994) had a study that examined how the monitoring of students' instruction generates a differential impact on student achievement transverse beyond school districts. The study listed two major mechanisms responsible for these effects: schools that vary in the monitoring placement and in the opportunities for instructional technique to students. The research elicited that monitoring placement could be affected by the degree of flexibility of track membership, school track structure, assignment criteria, and scheduling priorities. The study specifically focuses on student achievement and projected outlook.

Public schools must meet the expectations of the both the parents and the children as each child is entitled to a quality education. Smith and Meier (1995) wrote an article that was concentrated on the public choice and its needs for quality education. The research focused on school choice in addition to its popular education reform. It also noted the fact that the schools that did meet the needs of both the students and parents will draw more students and 
grow, while schools who do not will get less funding and close. While public schools are more efficient for families in the area, private schools allow for a more quality education. The problem lies when parents cannot afford private school for their child. If not, they must rely on the public-school system to provide the best education for their child. While some children make it through the system, there are many that fall through the cracks (Capochino, 2006). Even with successful students in the New Orleans public school system, there are many that have been left behind due to insufficient funds, ignorance of academics, and a negative outlook on life that may lead to death or prison (Martel, 2000).

\section{Data Analysis}

Through the years, New Orleans has consistently ranked near last regarding education, crime, and poverty. In reviewing statistical data, there is a clear correlation between low education and high poverty as well as low education and high crime rates.

Table 1. Education and Louisiana

\begin{tabular}{cc}
\hline Louisiana & Student's Score \\
\hline Orleans Parish (New Orleans) & below $50^{\text {th }}$ percentile on Leap Test \\
Jefferson Parish (surrounding cities) & below 50th percentile on Leap Test \\
St. Bernard Parish & above the 75 th percentile \\
Tangipahoa Parish & above the $70^{\text {th }}$ percentile \\
\hline
\end{tabular}

There is also a correlation between high poverty and crime rates in New Orleans. This suggests that many people surrounded by poverty are eager to become liberated by any means necessary. By viewing the low education rates, it is almost obvious that low education productivity affects a student's ability to strive toward success academically. This would in turn provide options that steer them away from committing crime or becoming a victim of poverty.

Table 2. Murder rates were calculated based on the FBI Uniform Crime Reports and the estimates -2015

\begin{tabular}{cccc}
\hline State & $\begin{array}{c}\text { Population } \\
\text { (total inhabitants) } \\
(2015)[1]\end{array}$ & $\begin{array}{c}\text { Murders and } \\
\text { Non-Negligent } \\
\text { Manslaughter } \\
\text { (total deaths) } \\
(2015)[2]\end{array}$ & $\begin{array}{c}\text { Murder and } \\
\text { Non-Negligent } \\
\text { Manslaughter Rate } \\
\text { (per 100,000 } \\
\text { inhabitants) 2015 }\end{array}$ \\
\hline Alabama & $4,853,875$ & 348 & 7.2 \\
Alaska & 737,709 & 59 & 8 \\
Arizona & $6,817,565$ & 309 & 4.5 \\
Arkansas & $2,977,853$ & 181 & 6.1 \\
& & & \\
& & 4 &
\end{tabular}


California

Colorado

Connecticut

Delaware

District of Columbia

Florida

Georgia

Hawaii

Idaho

Illinois

Indiana

Iowa

Kansas

Kentucky

Louisiana

Maine

Maryland

Massachusetts

Michigan

Minnesota

Mississippi

Missouri

Montana

Nebraska

Nevada

New Hampshire

New Jersey

New Mexico

New York

North Carolina

North Dakota

Ohio

Oklahoma

Oregon

Pennsylvania

Rhode Island

South Carolina

South Dakota
$38,993,940$

$5,448,819$

$3,584,730$

944,076

670,377

$20,244,914$

$10,199,398$

$1,425,157$

$1,652,828$

$12,839,047$

$6,612,768$

$3,121,997$

2,906,721

4,424,611

4,668,960

$1,329,453$

$5,994,983$

$6,784,240$

$9,917,715$

$5,482,435$

2,989,390

$6,076,204$

$1,032,073$

$1,893,765$

2,883,758

$1,330,111$

$8,935,421$

2,080,328

$19,747,183$

$10,035,186$

756,835

$11,605,090$

$3,907,414$

$4,024,634$

$12,791,904$

$1,055,607$

$4,894,834$

857,919
1,861

176

117

63

162

1,041

615

19

32

744

373

72

128

209

481

23

516

128

571

133

259

502

36

62

178

14

363

117

609

517

21

500

234

99

658

29

399

32
4.8

3.2

3.3

6.7

24.2

5.1

6

1.3

1.9

5.8

5.6

2.3

4.4

4.7

10.3

1.7

8.6

1.9

5.8

2.4

8.7

8.3

3.5

3.3

6.2

1.1

4.1

5.6

3.1

5.2

2.8

4.3

6

2.5

5.1

2.7

8.2

3.7 


$\begin{array}{cccc}\text { Tennessee } & 6,595,056 & 406 & 6.2 \\ \text { Texas } & 27,429,639 & 1,316 & 4.8 \\ \text { Utah } & 2,990,632 & 54 & 1.8 \\ \text { Vermont } & 626,088 & 10 & 1.6 \\ \text { Virginia } & 8,367,587 & 383 & 4.6 \\ \text { Washington } & 7,160,290 & 211 & 2.9 \\ \text { West Virginia } & 1,841,053 & 70 & 3.8 \\ \text { Wisconsin } & 5,767,891 & 240 & 4.2 \\ \text { Wyoming } & 586,107 & 16 & 2.7\end{array}$

While this information seemed more relevant to the research itself, more data could have been seen over the course of time, rather than total and per capita. One or the other would have sufficed, but both data points were rendered unnecessary when given nothing to compare it to. Had particular states been specifically targeted, especially seeing as data should have been related to the city of New Orleans over the state of Louisiana, the data would have been easier to disseminate.

Table 3. Persons below Poverty Level by State, 2014

\begin{tabular}{cccccc}
\hline Rank & State & $\begin{array}{c}\text { Poverty Rate } \\
\text { (by } \\
\text { Household } \\
\text { Income) }\end{array}$ & $\begin{array}{c}\text { People in } \\
\text { Poverty (by } \\
\text { Household } \\
\text { Income) } \\
\text { (in thousands) }\end{array}$ & $\begin{array}{c}2014 \\
\text { Poverty } \\
\text { Rates }\end{array}$ & $\begin{array}{c}\text { Supplemental } \\
\text { Poverty Measure } \\
(2010-2014 \text { average) }\end{array}$ \\
\hline- & United States & $14.80 \%$ & 45,950 & & $16.0 \%$ \\
1 & New Hampshire & $9.20 \%$ & 117 & $9.50 \%$ & $15.50 \%$ \\
2 & Maryland & $10.40 \%$ & 604 & $9.60 \%$ & $10.10 \%$ \\
3 & Wyoming & $10.60 \%$ & 54 & $9.30 \%$ & $9.20 \%$ \\
4 & Connecticut & $10.80 \%$ & 376 & $10.60 \%$ & $12.5 \%$ \\
5 & North Dakota & $11.10 \%$ & 79 & $11.00 \%$ & $9.20 \%$ \\
6 & New Jersey & $11.10 \%$ & 972 & $13.70 \%$ & $13.9 \%$ \\
7 & Minnesota & $11.40 \%$ & 607 & $12.10 \%$ & $9.70 \%$ \\
8 & Alaska & $11.40 \%$ & 81 & $12.10 \%$ & $12.50 \%$ \\
9 & Hawaii & $11.50 \%$ & 158 & $12.60 \%$ & $17.30 \%$ \\
10 & Massachusetts & $11.70 \%$ & 760 & $10.90 \%$ & $13.80 \%$ \\
11 & Virginia & $11.80 \%$ & 955 & $10.80 \%$ & $13.30 \%$ \\
12 & Utah & $11.80 \%$ & 341 & $9.80 \%$ & $11.60 \%$ \\
13 & Colorado & $12.10 \%$ & 632 & $12.40 \%$ & $13.70 \%$ \\
14 & Vermont & $12.20 \%$ & 72 & $9.70 \%$ & $13.4 \%$
\end{tabular}




\begin{tabular}{|c|c|c|c|c|c|}
\hline & $\begin{array}{l}\text { vacroth } \\
\text { nstitute }\end{array}$ & & & of Public & $\begin{array}{l}\text { Management Research } \\
\text { ISSN } 2377-3294 \\
\text { 2020, Vol. 6, No. } 2\end{array}$ \\
\hline 15 & Nebraska & $12.30 \%$ & 167 & $10.00 \%$ & $9.8 \%$ \\
\hline 16 & Iowa & $12.30 \%$ & 368 & $10.90 \%$ & $8.60 \%$ \\
\hline 17 & Delaware & $13.00 \%$ & 118 & $12.40 \%$ & $13.90 \%$ \\
\hline 18 & Wisconsin & $13.20 \%$ & 737 & $11.10 \%$ & $10.80 \%$ \\
\hline 19 & Washington & $13.20 \%$ & 913 & $11.90 \%$ & $12.20 \%$ \\
\hline 20 & Kansas & $13.50 \%$ & 381 & $13.90 \%$ & $11.50 \%$ \\
\hline 21 & Pennsylvania & $13.60 \%$ & 1,679 & $11.20 \%$ & $12.60 \%$ \\
\hline 22 & Maine & $14.00 \%$ & 181 & $11.60 \%$ & $11.20 \%$ \\
\hline 23 & South Dakota & $14.10 \%$ & 115 & $14.30 \%$ & $10.60 \%$ \\
\hline 24 & Illinois & $14.30 \%$ & 1,802 & $13.30 \%$ & $15.20 \%$ \\
\hline 25 & Rhode Island & $14.80 \%$ & 149 & $13.20 \%$ & $13.60 \%$ \\
\hline 26 & Idaho & $14.80 \%$ & 237 & $13.90 \%$ & $11.80 \%$ \\
\hline 27 & Montana & $15.20 \%$ & 151 & $13.50 \%$ & $12.10 \%$ \\
\hline 28 & Indiana & $15.20 \%$ & 968 & $16.40 \%$ & $14.20 \%$ \\
\hline 29 & Nevada & $15.40 \%$ & 430 & $13.10 \%$ & $19.80 \%$ \\
\hline 30 & Missouri & $15.50 \%$ & 908 & $15.60 \%$ & $12.40 \%$ \\
\hline 31 & Ohio & $15.80 \%$ & 1,778 & $13.50 \%$ & $13.20 \%$ \\
\hline 32 & New York & $15.90 \%$ & 2,760 & $15.90 \%$ & $18.1 \%$ \\
\hline 33 & Michigan & $16.20 \%$ & 1,567 & $27.60 \%$ & $13.50 \%$ \\
\hline 34 & Oregon & $16.40 \%$ & 637 & $7.11 \%$ & $10.30 \%$ \\
\hline 35 & California & $16.40 \%$ & 6,253 & $15.50 \%$ & $23.80 \%$ \\
\hline 36 & Oklahoma & $16.60 \%$ & 623 & $13.00 \%$ & $13.40 \%$ \\
\hline 37 & Florida & $16.60 \%$ & 3,231 & $14.60 \%$ & $19.5 \%]$ \\
\hline 38 & Texas & $17.20 \%$ & 4,519 & $17.40 \%$ & $16.40 \%$ \\
\hline 39 & North Carolina & $17.20 \%$ & 1,663 & $17.00 \%$ & $14.20 \%$ \\
\hline 40 & South Carolina & $17.90 \%$ & 838 & $13.80 \%$ & $15.80 \%$ \\
\hline 41 & Tennessee & $18.20 \%$ & 1,165 & $16.70 \%$ & $15.50 \%$ \\
\hline 42 & Arizona & $18.20 \%$ & 1,195 & $21.30 \%$ & $18.80 \%$ \\
\hline 43 & West Virginia & $18.30 \%$ & 328 & $16.00 \%$ & $12.90 \%$ \\
\hline 44 & Georgia & $18.40 \%$ & 1,298 & $18.50 \%$ & $18.20 \%$ \\
\hline 45 & $\begin{array}{l}\text { District of } \\
\text { Columbia }\end{array}$ & $18.40 \%$ & 114 & $18.00 \%$ & $22.7 \%$ \\
\hline 46 & Arkansas & $18.70 \%$ & 539 & $19.10 \%$ & $16.50 \%$ \\
\hline 47 & Kentucky & $19.00 \%$ & 812 & $17.10 \%$ & $13.60 \%$ \\
\hline 48 & Alabama & $19.20 \%$ & 905 & $16.80 \%$ & $13.50 \%$ \\
\hline 49 & Louisiana & $19.90 \%$ & 898 & $14.30 \%$ & $18.5 \%$ \\
\hline 50 & New Mexico & $20.60 \%$ & 347 & $19.60 \%$ & $16.10 \%$ \\
\hline 51 & Mississippi & $21.90 \%$ & 634 & $23.20 \%$ & $16.1 \%$ \\
\hline
\end{tabular}




\section{Macrothink}

What helped this data is that the data was allowed and available to be compared to the national numbers. Having the total number of people in poverty listed in the country, while also having the data available by individual state truly helped show the proportion between state and nation. However, this data could have been tabulated as well, showing what percentage of the country's poverty is held by each state. The supplemental poverty measure was over a period of time, which could have been even further broken down to identify each year individually. Again, had the data been shown by major city over state, the data would have been more relevant, overall helpful, to the research.

Table 4. Public School Teachers' Average Salaries, 2012-2013

\begin{tabular}{|c|c|c|}
\hline State & Starting Salary & Average Salary \\
\hline Alabama & $\$ 36,198$ & $\$ 47,949$ \\
\hline Alaska & $\$ 44,166$ & $\$ 65,468$ \\
\hline Arizona & $\$ 31,874$ & $\$ 49,885$ \\
\hline Arkansas & $\$ 32,691$ & $\$ 46,631$ \\
\hline California & $\$ 41,259$ & $\$ 69,324$ \\
\hline Colorado & $\$ 32,126$ & $\$ 49,844$ \\
\hline Connecticut & $\$ 42,924$ & $\$ 69,397$ \\
\hline Delaware & $\$ 39,338$ & $\$ 59,679$ \\
\hline Florida & $\$ 35,166$ & $\$ 46,598$ \\
\hline Georgia & $\$ 33,664$ & $\$ 52,880$ \\
\hline Hawaii & $\$ 41,027$ & $\$ 54,300$ \\
\hline Idaho & $\$ 31,159$ & $\$ 49,734$ \\
\hline Illinois & $\$ 37,166$ & $\$ 59,113$ \\
\hline Indiana & $\$ 34,696$ & $\$ 50,065$ \\
\hline Iowa & $\$ 33,226$ & $\$ 50,946$ \\
\hline Kansas & $\$ 33,386$ & $\$ 47,464$ \\
\hline Kentucky & $\$ 35,166$ & $\$ 50,203$ \\
\hline Louisiana & $\$ 38,655$ & $\$ 51,381$ \\
\hline Maine & $\$ 31,835$ & $\$ 48,430$ \\
\hline Maryland & $\$ 43,235$ & $\$ 64,248$ \\
\hline Massachusetts & $\$ 40,600$ & $\$ 72,334$ \\
\hline Michigan & $\$ 35,901$ & $\$ 61,560$ \\
\hline Minnesota & $\$ 34,505$ & $\$ 56,268$ \\
\hline Mississippi & $\$ 31,184$ & $\$ 41,814$ \\
\hline Missouri & $\$ 30,064$ & $\$ 47,517$ \\
\hline Montana & $\$ 27,274$ & $\$ 48,855$ \\
\hline Nebraska & $\$ 30,844$ & $\$ 48,997$ \\
\hline Nevada & $\$ 35,358$ & $\$ 55,957$ \\
\hline
\end{tabular}


New Hampshire

New Jersey

New Mexico

$\$ 31,960$

$\$ 45,453$

New York

$\$ 43,839$

$\$ 75,279$

North Carolina

$\$ 30,778$

$\$ 45,737$

North Dakota

$\$ 32,019$

$\$ 47,344$

Ohio

$\$ 33,096$

$\$ 56,307$

Oklahoma

$\$ 31,606$

$\$ 44,373$

Oregon

$\$ 33,549$

$\$ 57,612$

Pennsylvania

$\$ 41,901$

$\$ 62,994$

Rhode Island

$\$ 39,196$

$\$ 63,474$

South Carolina

$\$ 32,306$

$\$ 48,375$

South Dakota

$\$ 29,851$

$\$ 39,018$

Tennessee

$\$ 34,098$

$\$ 47,563$

Texas

$\$ 38,091$

$\$ 48,819$

Utah

$\$ 33,081$

$\$ 49,393$

Vermont

$\$ 35,541$

$\$ 52,526$

Virginia

$\$ 37,848$

$\$ 48,670$

Washington

$\$ 36,335$

$\$ 52,234$

West Virginia

$\$ 32,533$

$\$ 45,453$

Wisconsin

$\$ 33,546$

$\$ 53,797$

Wyoming

$\$ 43,269$

$\$ 56,775$

\section{Results}

Through extensive research, the findings show that there is a high correlation between high poverty and crime. Regarding major cities such as New Orleans, Los Angeles, New York City, Atlanta and Miami, many prominent correlations exist. In reviewing the statistics of the state of Louisiana, the findings show that here is a high correlation between poverty and crime. Louisiana ranked at number one regarding persons living below the poverty level" and sixth in violence and crime

Overall, the data submitted for this research was very inconsistent in more ways than one. Firstly, and arguably most importantly, hardly any of the data was taken around the same time, which makes it difficult to effectively compare and correlate the findings. Without proper means to correlate the findings and find patters, actual findings are difficult to substantiate and conclude. The research should be reevaluated and submitted for further review.

\section{Conclusion}

There are many limitations within this research paper. ACT and SAT scores should have been reviewed over Leap Test scores. The results of the study may have been easily correlated to 
academic improvement if actual test scores of the students were collected during this time period. Another limit on this research study is the actual period when the research data was collected from resources from previous years as they may not reflect Post-Katrina New Orleans. Hurricane Katrina caused many political leaders to realize the decline in the New Orleans public school system and the impact on its students. The post-Katrina school board was more eager to recreate decent environments for its students as well as an optimistic future. It is not only up to the school board to make a difference in the educational environment within the city. This study should have also narrowed its topic toward Black Americans in New Orleans. This would have further objectified the research as they make up seventy-five percent of the city, ninety percent of public schools, and the majority of the poverty and crime.

In conclusion, there are many factors that may have an impact on the public-school system of many other major cities. However, in this report, it seemed that hardly any of the data actually related to the research itself, as much of the report is written with a lens of emotion rather than objectivity. This subjective nature to the data given and report leave it difficult to disseminate and fully digest.

\section{References}

“Teaching Salary Data by State." Teacher Salaries by State, Average Salaries For Teachers, Beginning Salaries For Teachers, Teacher Raises, Violent Crime. (2014). Statistical Abstract of the United States Census Bureau. Retrieved from http://www.census.gov/statab/ranks/rank21.html

Capochino, A. (2006). Seven New Orleanians elected to Orleans Parish School board seems ready to change (p. 1). City Business. New Orleans.

Domanico, R. (1994). Undoing the failure of large school systems: Policy options for school autonomy. Journal of Negro education, 63(1), 19-27.

Hallinan, M. T. (1994). School differences in tracking effects achievement. Social Forces, 72(3), 799-820.

Jensen, L. (2006). La. ranks 49th in nurturing kids; improvement noted, but only Miss (p. 1). Lower. Times Picayune. New Orleans.

LaCour, N. (2002). The real accomplishments of public education and the false promise of Vouchers. Journal of Negro Education, 71, 5-16.

Martel, B. (2000). Crime, poverty afflict area of N.O. shootings (p. 12). Advocate. Rouge.

Meier, K. J., \& Smith, K. B. (1995). Public choice in education: markets and the demand for quality education. Political Research Quarterly, 48(3), 461-478.

Persons below Poverty Level. (2003). Statistical Abstract of the United State Census Bureau. Retrieved from http://www.census.gov/statab/ranks/rank21.html

Sik Kee, W. (1969). The causes of urban poverty: a comment on discrimination. Journal of Human Resources, 93-99. 
Staff. (2004). New Orleans ranked as third most stressful city. City Business (p. 1). Metairie.

Stern, W. (1999). LA. Ranked worst state for children abuse poverty, teen crime among Factors considered. Times Picayune (p. A1). New Orleans.

\section{Copyright Disclaimer}

Copyright for this article is retained by the author(s), with first publication rights granted to the journal.

This is an open-access article distributed under the terms and conditions of the Creative Commons Attribution license (http://creativecommons.org/licenses/by/4.0/). 